\title{
Disciplinary Changes in Science Education in Hungary in the Era of the Stalinist Dictatorship
}

\author{
IMre GARAi AND ANDRÁs NÉMETH
}

\begin{abstract}
In our paper we intend to summarize the main results of our research about the structural and disciplinary changes in Hungarian higher education in the early part of the 1950 s.

In the first part of our paper we point out the basic elements of the theoretical background to the research. Stichweh's notion of disciplines, Bourdieu's theory of 'scientific fields', and Voegelin's concept of 'political religion' made it possible to describe and analyze the complex phenomena involved in the socialist transformation of Hungarian higher education. Then, in the second part of the paper, we analyze the main data gained from archival research into the structural changes in higher education institutions by using the theoretical notions mentioned above.

As a result of our research, we are able to determine some peculiarities of the socialist higher education policy and socialist educational discipline.
\end{abstract}

Keywords: socialist notion of discipline, scientific field, Sovietization of higher education, Soviet influence in Central-Eastern Europe

Our paper is based on the results of a significant research study dealing with the period of the Stalinist dictatorship, which ended recently and was financed by the Hungarian Scientific Research Fund. ${ }^{1}$ We will examine those factors which profoundly transformed the whole structure of universities and academic sciences and the discipline of education as a part of this structure in Hungary in the era of the Rákosi dictatorship (1949-1953). ${ }^{2}$

Our approach is based on a newlyemerging theme which examines the Soviet-type development of science in what are now post-Soviet countries. Researchers recently began to show interest in the

\footnotetext{
${ }^{1}$ This paper summarizes the main conclusions of two papers in the final report of the research. In these papers we examined the changes in Hungarian higher education and the transformation of the discipline of education (Garai, 2016; Németh, 2016).

${ }^{2}$ The name of the era alludes to the supreme rule of Mátyás Rákosi, who was the general secretary of the Hungarian Workers' Party (HWP, the name of the Hungarian Communist Party) between 1945 and 1953 and the prime minister in 1952 and 1953 . He was the supreme political leader in this period.
} 
pedagogical phenomenon of "existing Socialism". We also intend to examine the pedagogical peculiarities of the communist-socialist dictatorship in Hungary.

The core sources of our paper were provided by research into archival sources (university and ministerial materials, reports of scientific institutions and scientific events) and the relevant secondary literature about the topic (scientific book series, textbooks, and journals) between 2010 and 2015.

\section{THEORETICAL FRAMEWORKS OF OUR RESEARCH}

Robert Merton's theory about the sociology of science began to establish a new theoretical and methodological approach to research on the sociology of science in the United States in the last decades of the twentieth century. To modify his concept, he also used the empirical 'structural functionalist' sociological theory of Talcott Parsons. One European receptionist trend of the theories of Parsons and Merton emerged in the work of Niklas Luhmann. We used the notion of discipline, which was worked out by Luhmann's follower, Rudolf Stichweh, and became widespread in research on the history of science (Stichweh, 1994). Following these theoretical concepts, some monographs and edited volumes have been published in recent decades which examined the development of the discipline of education from the viewpoint of social history (Drewek \& Lüth, 1998; Horn, 2003; Horn et al., 2001).

One of the core elements of our research is based on a macro theoretical viewpoint, Stichweh's notion of scientific disciplines. This notion is widely used in historical research on science which has an orientation towards the sociology of knowledge, and it is also used in systematic research on the theory of science (Becker, 1989; Stichweh, 1994). Scientific works and scholars are also an essential part of science according to Stichweh's notion of disciplines (autonomous scientific fields). The identification of disciplines in this sense has four components: a) an institutional infrastructure background to research, b) a scientific communication network, c) cognitive products of the discipline, and d) support for young scientists' socialization.

In order to grasp the micro-patterns of the development of science, we used Bourdieu's 'socio-analytical' concept, which was originally worked out to examine the deeper layer of society, and we also adopted categories and the structure of the notions of his concept about the theory of scientific fields as a second core element of our research (Bourdieu, 2005). According to Bourdieu, most societies are constructed from functional spaces which can be recognized by different structures of the society. These spaces constitute the actual existing social universe, which can vary in time and space - the distribution structure forms of power or capital types. Because there is constant change, there is a need for a typology which can describe the current form of social positions, and it is also useful in the dynamic examination of the modifications of social positions. Bourdieu thought that this criterion may be fulfilled 
if social space is interpreted as a dynamic activity field. On the one hand, this field necessarily affects the agents as a summary of compelling forces. On the other hand, this field also serves as a battlefield where agents can fight with each other. The enforcement of interests within the field is determined by power relations and the harmony of tools and aims related to this relationship (Bourdieu, 2002, pp. 44-48).

Widening the theoretical background of our research towards the theory of fields means that in our research we examine how a discipline creates a field constructed from institutional and cognitive elements (Bourdieu, 2005). Its macrostructure is based on the adaption of Stichweh's notion of disciplines and the tight interconnection of the above-mentioned four elements which can be interpreted in historical processes (Schriewer et al., 1993):

1. formation of the institutional basis historical processes of the professionalization of research: emergence and formation of the preconditions of a given disciplinary field (scientific field);

2. historical development processes of communication networks: a discipline (specific scientific field) that includes its scholars and forms a homogenous community which specializes in solving common issues (scientific community);

3. historical processes of forming the different cognitive products of scientific recognition: the institutional and communicational infrastructure of the disciplinary field provides for the formation of common scientific results, which are subject to scientific recognition;
4. historical processes of the training of young scientists and their professional socialization: the institutional function of a given disciplinary field is to transfer the knowledge of the discipline to the next generation of professionals and provide their professional education and socialization. This guarantees the selection of professionals from the disciplinary corpus, the clear delineation of the boundaries of the discipline, and the function of selection mechanisms which can maintain scientific standards.

During our research, we used Bourdieu's theory and his structure of notions about the functioning of scientific fields as a part of his theory on the concept of activity in order to be able to analyze the abovementioned four dimensions (Bourdieu, 2005). According to his theory, all scientific disciplines create their own scientific fields, which have their own structures and also function as a space for competition that helps maintain and restructure the field. A scientific field is formed and developed by the relationship of the agents who perform within it. Moreover, the scientific discipline is a kind of space for competition, a socially constructed field for performing, and a space where agents with different capabilities can confront each other to maintain or transform the current situation of the field.

The specific habits which relate to a specific scientific discipline are developed in this field. According to Bourdieu, this is the personalization of the scientific field. Scholars who master the peculiarities of the scientific field have the same perceptual 
structures as their field does, and therefore they can constantly comply with its current expectations. The habits of scholars can be different according to the peculiarities of each scientific field, but they can also be influenced by other factors such as their origin or social or professional career.

Disciplines construct fields which are separate from each other but are constant and can be clearly identified: a) they have well-known names which have gained prestige in educational, social, and disciplinary spaces; b) they have independent and autonomous departments, laboratories, journals, international forums, processes for certifying professional knowledge, payment methods, and awards; c) they have their own independent scientific style; d) prestigious scientific disciplines have their own strictly codified boundaries, and e) disciplines' rank in the hierarchy of sciences depends on the commonly accumulated capital and their independence from political, confessional, or economic influence (Bourdiueu, 2005).

As a consequence of the political character of the Rákosi era, we used the notion of political religion as a third core element of our research (Baska, 2015). The classic work that pointed out and analyzed the significance of political religion was written by Eric Voegelin in the 1930s (Voegelin, 1936). According to his final conclusions, the history of humankind moves forward from transcendental religious beliefs (überweltlich) to inwardly-oriented beliefs (innerweltlich) and ideologies (Balogh, 2011). The latter deem themselves to be the only possible option of reality that can be possessed by a certain race, class, or even nation. This historic process leads to the emergence of 'modern gods' when using the symbols of religion and fulfilling its functions would result in the replacement of God with politics or science. As a result of this process, perceptions about the world will appear as unlimited knowledge that has a tight connection with historical processes. The very end of these historical processes is the end of history, when there is a possibility of salvation as a result of the emergence of the perfect conditions of humanity.

The notion introduced by Voegelin that provides a tool for describing the characteristics of totalitarian regimes in the twentieth century recently became popular (Gentile, 2000, 2003; Harting, 2008). Gentile, in his work about the sacralization of politics (2000), pointed out that totalitarian regimes always want to take over the country in a legal or illegal way and create a political system in which the new government suppresses the whole society. The new rulers try to transform the whole society through an anthropological revolution. Thus the members of the transformed society are willing to fully accept the main aims of the Party by subordinating all aspects of their personalities in order to create and establish a supranational civilization.

Consequently, political religions transform a totalitarian political ideology into a sacral phenomenon that behaves intolerantly towards rival political movements. Thus they make attempts to eliminate these competing 'prophecies'. Private interest-led 
activities are replaced by pressure with the aim of fulfilling the goals of the political elite without any hesitation. New sacral rituals provide a behavioural scheme and ethical codex for the community. By the use of violence, the political elite can force the population to comply with these socialization schemes. Representatives of the political system who comply perfectly with the political regulations are admired as 'saints'. All the subsystems of the society are eager to reach the Messianic aim of the party, which is to create a utopian communist society. The education system, as an important element of the social subsystems, has a significantly important responsibility in this process.

\section{NATIONALIZATION OF HIGHER EDUCATION, PECULIARITIES OF THE COMMUNIST DISCIPLINE OF EDUCATION}

As a result of political and economic transformation, a new era began in the history of Hungarian higher education that prepared the profound changes in this sphere in the 1950s. The communist perception of science, which rejected the principles of Western-type scientific norms, paradigmatically transformed the institutions and infrastructures of the Scientific Academy and universities. It managed to alter the socialization scheme of the scientists, communication structures, and the meaning of scientific work.

These changes together created the communist-socialist discipline model, which was profoundly different from the specific features of the Western-type perception of science. This socialist model neglected meritocratic standards and its indoctrination functions and quasi-religious attitude almost wiped out the traditional forms of creating scientific products. Disciplines' social acceptance and their recruitment processes also changed significantly.

Scientific development in the discipline of education also changed after the new phase that began after 1945. Its function was determined by the basic dichotomy of the communist ideology, which divided the world into two different parts. According to this quasi-theologicallyoriented rhetoric, the faith of the world is determined by the struggle between heavenly and evil forces. The Communist Party, which represented the good side in this struggle, made the scientific disciplines serve the purpose of the peace of humankind and it founded new scientific institutions which made the economic process more predictable and purposeful. Representatives of the other, evil side were aggressors and profit-hunting capitalists who wanted to deter science from further development. The basic character of the Stalinist-type dictatorship's rhetoric was provided by epic cultural indoctrination which displaced abstraction and the cognitive approach.

The process of the nationalization of higher education began in the first half of 1949 with the announcement of Ministerial Decree 260/1949 (12 $2^{\text {th }}$ January). After the announcement of this decree, reforms 
of universities and the Scientific Academy were declared in the sessions of the Secretariat of the Hungarian Workers' Party (HWP) every half-year.

The Party only let the public know that there were some important reforms in the sphere of higher education. Communist politicians highlighted the fact that more students were allowed to attend academies and universities than before, ${ }^{3}$ and the financial support provided to these spheres also increased in a way that had never been expected. ${ }^{4}$ On the level of higher education policy, the party restructured the scientific field because the governing and authorizing role of the Ministry of Religion and Public Education changed profoundly. In parallel with the criticism of each department of the Ministry, the party separated a few areas from it and set up new institutes to authorize these separated fields (Kalmár, 2014, p. 58)..$^{5}$ As a result of the criticism that reached the Department of Universities and Academies of the Ministry, this organization was also transformed and its authority concerning the supervision of the affairs of universities and academies was limited.

The other direction of the transformation of the scientific institute was achieved by the $27^{\text {th }}$ Act of Parliament in 1949, which resulted in the integration of the Hungarian Scientific Committee and the Hungarian Scientific Academy. By announcing this act, the Communist Party was able to achieve the transformation of the Scientific Academy by supporting an organization which was comprised of communist scholars. Before the proclamation of the unification, the party had carefully selected those scholars who were considered fit to be members of the reformed Academy in political and scientific terms. ${ }^{6}$ By implementing this process, the party had to reach the conclusion that there were only a few scholars who were really committed to its political aims. Therefore, it accepted the natural political behaviour of all scholars except those scientists in the humanities and social disciplines. ${ }^{7}$ The transformation of the boundaries of the scientific field was not over at the end of 1949 because the HWP made the Scientific Academy responsible for the recruitment of young generations of scholars by setting up the Committee of Training Scientists (CTS). By implementing the training of aspiring scholars with the announcement of the $44^{\text {th }}$ decree in 1950 (26 $^{\text {th }}$ September), the controlling of Bourdeiu's notion

\footnotetext{
${ }^{3}$ Session of the Central Committee of the HWP on $27^{\text {th }}$ November 1948. Hungarian National Archive (HNA) fond 276, bunch 52, unit 4, pp. 41-42.

${ }^{4}$ Session of the Central Committee of the HWP on $2^{\text {nd }}$ April 1949. HNA f. 276, b. 52, u. 6, pp. 33-35.

${ }^{5}$ 2267/1949. Proposal for a bill about the transformation of the government of the Hungarian Republic. HNA f. 276, b. 54, u. 48, pp. 17-18.

${ }^{6}$ Alexits, György: Proposal to the Secretary about transforming the Hungarian Scientific Academy and Hungarian Scientific Committee. Budapest, September 1949. HNA f. 276, b. 54, u. 62, pp. 14-21.

${ }^{7}$ Alexits, György: Proposal about the members and structure of the Hungarian Scientific Academy. Budapest, $18^{\text {th }}$ October 1949. HNA f. 276, b. 54, u. 67, p. 29.
} 
of an 'entrance fee' became the task of the Academy. Thus, the Scientific Academy became the most important institute for authorizing Hungarian scientific institutions and their scholars. ${ }^{8}$ Besides the Academy, the scientific community was also transformed by the $26^{\text {th }}$ decree in 1951 $\left(11^{\text {th }}\right.$ November). By setting up the Committee of Scientific Ranking (CSR), ${ }^{9}$ the party appointed those scholars who were picked as Doctors of Sciences or Candidates of Sciences and thus they were given further 'permission to operate' in their own scientific field.

All in all, 340 applications were submitted to the CSR to decide about awarding higher scientific ranks to candidates. Only 81 scientists had memberships of the Communist Party. ${ }^{10}$ Therefore, the party wanted to have direct influence over certain scientific fields. In the case of scholars in the technical and natural sciences, they tried to persuade them or at least prove their natural political behaviour by means of the awarding of scholarships and promoting leading figures in these scientific fields to high administrative positions. The excessive support provided to these sciences can be perceived by examining the number of Soviet scholarships these scien- tists received ${ }^{11}$ and the appointment of institute directors in the case of the establishment of new universities from technical faculties. ${ }^{12}$ Furthermore, the asymmetric relationship between the natural sciences and human sciences can be explained by their different roles in fulfilling the aims of the first Five-Year Plan and the emergence of challenges in the Soviet sphere of influence in Europe which were results of the scientific-technical revolution (Kalmár, 2014, p. 73).

The Scientific Academy already authorized the scientific research and careers of scholars; moreover, the party hoped that it could achieve the direct government of all the universities by setting up a new governmental institute. The contours of the concept of the Higher Education Committee had become sharp by the second half of 1950 . The Party wanted to make the Committee a central authority of the higher education system near or instead of the Department of Universities and Academies of the Ministry of Religion and Public Education. Prominent politicians thought that the ministerial department could not cope with the operational governing task of the whole higher education system on its own.

\footnotetext{
8 Proposal about implementing training aspiring scholars. Budapest, $17^{\text {th }}$ August 1950. HNA f. 276, b. 54, u. 114, pp. 8-10. ${ }^{9}$ Horváth, Márton: Proposal about appointing the president, secretaries and members of the CSR. Budapest, $19^{\text {th }}$ November 1951. HNA f. 276, b. 54, u. 169, p. 69.

${ }^{10}$ Hungarian Scientific Academy: Report on promoting scholars to higher scientific ranks. $1^{\text {st }}$ group of university teachers. Budapest, $4^{\text {th }}$ July 1952 . HNA f. 276, b. 54, u. 201, p. 44.

${ }^{11}$ The HWP Central Directorate Agitation and Propaganda Committee's proposal about the distribution of scientific scholarships. Budapest, $11^{\text {st }}$ January 1949. HNA f. 276, b. 54, u. 26, p. 4.

${ }^{12}$ Friss, István: Proposal for the Secretary about decentralization and specialization of technical universities. Budapest, $2^{\text {nd }}$ June 1951. HNA f. 276, b. 54, u. 147, pp. 18-23.
} 
According to the inner logic of the Party, it just had to find the proper scholars for leading positions to gain total control over the whole of higher education because it had already transformed the structure of the university system and set up new governing authorities. The drawbacks of these methods became clear when the Party wanted to appoint vice-rectors and vice-deans. The HWP treated the nationalization of Hungarian higher education as a kind of governing question. They wanted to create total authorization by establishing narrow-profile universities for certain disciplines and picking politically loyal scholars to be the leaders of scientific institutes. However, the socialization of the new generation of scholars went extremely slowly in each discipline, and thus the scholars who were appointed as vicerectors turned out to be disloyal or hostile towards the general policy of the Party or could not support the changes in higher education. ${ }^{13}$ Consequently, the Secretariat had to remove the proposal from its agenda by concluding that the Party could not find enough trustworthy scholars to occupy leading positions. ${ }^{14}$ They postponed this question at the session of $5^{\text {th }}$ April 1951. The realization that the goal of total control over the sphere of higher education could not be fully achieved encouraged policymakers to change their methods.
The failure in appointing vice-rectors of universities forced the politicians involved in the sphere of higher education to seek a new method for continuing the process of nationalization. By this time, the Party had strengthened its organizations again in order to keep a tight rein on universities and the Scientific Academy. Nevertheless, it was not satisfied with implementing governing reforms. Therefore, it took additional political measures to improve its control over higher education. By transforming the structure of examinations and eliminating the remaining elements of bourgeois pedagogy, the Party wanted to change the governing system. The concept of setting up an independent Higher Education Ministry following the Soviet pattern came from the idea that the new institute should combine the Academy's theoretical scientific governing role with universities' tasks of conducting research and training young scholars by means of tight control by the new ministry. ${ }^{15}$

In fact, setting up the independent Higher Education Ministry served not just as a tool for improving governmental authority over universities. It provided the government with an opportunity to manage and influence directly the teaching methods of universities and research projects in the case of all sciences. It was also expected to be the final step of trans-

\footnotetext{
13 "He made snide remarks about the people's democracy. He is not developed enough in the ideological aspect, he had clerical sentiments." Cadre description of Dr József Varó. Budapest, $9^{\text {th }}$ March 1951. HNA f. 276, b. 54, u. 134 , p. 80.

${ }^{14}$ Record about proposals of vice-rectors and vice-deans. Budapest, $9^{\text {th }}$ March 1951. HNA f. 276, b. 54, u. 134, p. 89. ${ }^{15}$ Horváth, Márton: The current situation of our higher education system and its governing system. Budapest, $21^{\text {st }}$ April 1952. HNA f. 276, b. 54, u. 190, pp. 14-19.
} 
forming the whole scientific field because in the previous phases of the nationalization process, the Party had already regulated and authorized the 'entrance fee'; the function of scientific societies had been restructured and the influence of the methods of certain scientific fields had also been determined since the previous stages of the nationalization process. ${ }^{16}$

By 1952, very few elements of the structure of the universities were reminiscent of the Humboldt-type university model that had been formed by following the neohumanist scientific philosophy in Central-Eastern Europe in the second half of the nineteenth century. The structure of Hungarian higher education began to resemble the Soviet and French pattern of universities by creating narrow-profile universities. The French system of higher education mainly comprised special lyceums and academies (grandes écoles) which were authorized by an administrative organization (the Imperial University) in the $19^{\text {th }}$ century. These patterns had some common features with the Russian and later Soviet higher education system (Tóth, 2001, pp. 99-101). The political elite began to realize these changes and therefore, they considered changing the names of universities and academies. Paradoxically, the newly-founded narrow-profile universities tended to be the most vehement opponents of this idea by referring to traditions. ${ }^{17}$ Thus, the Party had to abandon this idea and the politicians declared that the transformation of higher education would be completed by separating teacher training from vocational training at universities. After the death of Stalin, political changes in Central-Eastern European countries, including Hungary, made it impossible to implement this idea, which was realized only in the second half of the 1950s.

By restricting the autonomy of elite scholars at universities and in the Scientific Academy, the characteristic features of the Soviet-type university model became even more dominant. The institutionalized form of this phenomenon is the 'nomenklatura' system. The members of the nomenklatura were those individuals who were appointed to be officials by different levels of the Party. The socialist-communist scholarly elite became an ideology-producing elite instead of examining natural and social phenomena by using traditional and strictly controlled scientific methods. Their most important task was to serve the interests of the expanding political field.

\section{SUMMARY - PECULIARITIES \\ OF THE COMMUNIST SCIENTIFIC POLICY AND DISCIPLINE}

By examining the changes in the discipline of education, we can conclude that it was strongly characterized by the profound transformation of the autonomy/

\footnotetext{
${ }^{16}$ Horváth, Márton: Record about the current situation of our higher education system and its governing system. Budapest, $21^{\text {st }}$ April 1952. HNA f. 276, b. 54, u. 190, p. 3.

${ }^{17}$ 2180/52.VIII.19. Horváth, Márton: Proposal about the names of academies and universities. Budapest, $19^{\text {th }}$ August 1952. HNA f. 276, b. 54, u. 207, pp. 170-171.
} 
heteronomy relations of the previously autonomous scientific field. The formation of the basic elements of the one-party state created the political conditions for changing the whole spectrum of the scientific field. Institutional frameworks for providing autonomy and standards of scientific work ceased to exist and were replaced by collective governing boards. This resulted in the elimination of the autonomy of Hungarian disciplinary spaces which had been relatively free from direct political influence.

Eliminating the autonomy of the scientific field, which also determined the function of the discipline of education in the first half of the century, resulted in serious consequences for all the components of the discipline of education. By following the norms of the nomenklatura, it became part of the political-ideological field, and this was authorized by the totalitarian measures of the new political system. Hungarian scholars with professional and scientific autonomy became members of the "priestly order" and they approached public and higher education with missionary zeal. They also created the "atheist theology" of the communist "state religion" and thus they also became part of the political field (Bourdieu, 2005).

Their new status as communicators of educational aims and measures declared by the state was amplified by two facts. First, at the very beginning of the transformation process the Hungarian Scientific
Council declared that in the case of social sciences the usage of a Marxist-Leninist approach was unavoidable. Philosophers, historians, and scholars of education should use this approach in order to be able to form the ideological background of the working class. Consequently, these scientific fields played an enormous role in creating a socialist society. ${ }^{18}$ Second, the professional framework of the discipline of education was transformed by eliminating professional organizations and limiting the operation of professors. As scientific academia was transformed, the members of the institute were also revised. "Bourgeois" professors of education were not allowed to obtain the newly-established scientific ranks. A new generation of scientists was promoted to new scientific ranks acknowledged by the state after the mid-1950s as a reward for their willingness to internalize the political declarations of the party and use them in their scientific papers (Golnhofer, 2006). As McClelland pointed out, specialist knowledge was what made professions so important in modern societies. This knowledge was institutionalized and became the source of their special position in society (McClelland, 1991, p. 11). Through the transformation of the professional knowledge of scientists of education, they became dependent upon political and ideological shifts. The only criterion by which their work was judged was the effectiveness of their adoption of the political intentions of the 1950s.

\footnotetext{
${ }^{18}$ Main directives of the working plan of the Hungarian Scientific Council in 1949. Budapest, $24^{\text {th }}$ February, 1949. HNA f. 276, b. 54, u. 31, p. 34.
} 


\section{REFERENCES}

Balogh L. L. (2011). Totalitarizmus és politikai vallások. Kommentár, 6(1). Retrieved April 15, 2016 from http://kommentar.info.hu/iras/2011_1/totalitarizmus_es_politikai_vallasok

Baska, G. (2015). Rituális elemek a Rákosi-korszak pedagógiai sajtójának propaganda szövegeiben. In G. Baska \& J. Hegedűs (Eds.), Égi iskolák, földi mühelyek (pp. 344-358). Budapest: ELTE PPK.

Becker, T. (1989). Academic tribes and territories. Intellectual enquiry and the cultures of disciplines. Buckingham: The Society for Research into Higher Education - Open University Press.

Bihari, M. (2005). Magyar politika 1944-2004. Politikai és hatalmi viszonyok. Budapest: Osiris Kiadó.

Bourdieu, P. (2002). A gyakorlati észjárás. Budapest: Napvilág Kiadó.

Bourdieu, P. (2005). A tudomány tudománya és a reflexivitás. Budapest: Gondolat Kiadó.

Drewek, P., \& Lüth, C. (Eds.). (1998). History of educational studies. Gent: C.S.H.P.

Garai, I. (2016). A magyar felsőoktatás strukturális átalakítási és államosítási kísérletei az 1949-1953 közötti időszakban. In A. Németh, I. Garai, \& Z. A. Szabó (Eds.), Neveléstudomány és pedagógiai kommunikáció a szocializmus idöszakában (pp. 119-160). Budapest: Gondolat Kiadó.

Gentile, E. (2000). Die Sakralisierung der Politik - Einige Definitionen, Interpretationen und Reflexionen. In H. Maier (Ed.), Wege in die Gewalt - Die modernen politischen Religionen (pp. 166-182). Frankfurt am Main: Fischer Taschenbuch.

Gentile, E. (2001). Le religioni della politica. Fra democrazie e totalitarismi. Roma: Laterza.

Golnhofer, E. (2006). Rendszerváltások a tudomány legitimációjában. In É. Szabolcs (Ed.), Pedagógia és politika a XX. század második felében Magyarországon (pp. 9-28). Budapest: Eötvös József Könyvkiadó.

Harting, A. S. (2008). Verheißung und Erlösung. Religion und ihre weltlichen Ersatzbildungen in Politik und Wissenschaft. Wien: Passagen.

Horn, K.-P. (2003). Erziehungswissenschaft in Deutschland im 20. Jahrhundert. Bad Heilbrunn: Klinkhardt.

Horn, K-P., Németh, A., Pukánszky, B., \& Tenorth, H.-E. (Eds.). (2001). Erziehungswissenschaft in Mitteleuropa. Aufklärerische Traditionen - deutscher Einfluß-nationale Eigenständigkeit. Budapest: Osiris Kiadó.

Kalmár, M. (2014). Történeti galaxisok vonzásában. Magyarország és a szovjetrendszer 1945 -1990. Budapest: Osiris Kiadó.

McClelland, C. E. (1991). The German experience of professionalization. Modern learned professions and their organizations from the early nineteenth century to the Hitler era. Cambridge - New York - Sydney: Cambridge University Press.

Németh, A. (2016). A neveléstudomány diszciplína jellemzőinek változásai a sztálini diktatúra időszakában. In A. Németh, I. Garai, \& Z. A. Szabó (Eds.), Neveléstudomány és pedagógiai kommunikáció a szocializmus idöszakában (pp. 7-118). Budapest: Gondolat Kiadó. 
Schriewer, J., Keiner, E., \& Charle, C. (1993). (Eds.). Sozialer Raum und akademische Kulturen. Frankfurt am Main: Lang-Internationalen Verlag der Wissenschaften.

Stichweh, R. (1994). Wissenschaft, Universität, Professionen. Frankfurt am Main: Suhrkamp.

Tóth, T. (2001). A napóleoni egyetemtől a humboldti egyetemig. In T. Tóth (Ed.), Az európai egyetem funkcióváltozásai. Felsöoktatási tanulmányok (pp. 95-124). Budapest: Professzorok Háza.

Voegelin, E. (1938/1993). Die politischen Religionen. Wien: Bermann-Fischer.

Dr. Imre Garai, Ph.D.

Eötvös Loránd University Budapest, History of Education Department, Research Group for Historical, Theoretical and Comparative Pedagogy;

e-mail: garai.imre@gmail.com

Prof. Dr. András Németh

Selye János University Komárno, Faculty of Education, Department of Pre-school and Elementary

Education;

e-mail: andras.nemeth@ujs.sk 